\title{
Desain Pengaturan Level pada Coupled Tank Process dengan Menggunakan Metode Model Predictive Control
}

\author{
Evira Dyah Puspitarini, Rushdianto Effendie, dan Josaphat Pramudijanto \\ Jurusan Teknik Elektro, Fakultas Teknologi Industri, Institut Teknologi Sepuluh Nopember (ITS) \\ Jl. Arief Rahman Hakim, Surabaya 60111 \\ E-mail: evirapuspitarini@gmail.com, rusdhi@elect-eng.its.ac.id, jos@elect-eng.its.ac.id
}

\begin{abstract}
Abstrak -- Plant level coupled tank digunakan pada kebutuhan industri yang melibatkan fluida sebagai penampung minyak atau cairan kimia. Coupled tank merupakan plant nonlinier yang tersusun dari dua buah tangki yang dihubungkan oleh sebuah pipa atau lubang saluran. Cara kerja dari tank ini dengan mengendalikan aliran dan laju air salah satu tangki sesuai kebutuhan. Kontrol level digunakan untuk menjaga titik set level terhadap nilai yang diberikan sehingga mampu menerima nilai-nilai set point secara dinamis.

Pada tugas akhir ini, digunakan metode Model Predictive Control untuk mengendalikan aliran dan laju air. Untuk mengaplikasikan Model Predictive Control, perumusan plant akan diubah menjadi plant linear. Penelitian tugas akhir ini bertujuan untuk mendesain sistem pengendalian level dan flow pada coupled-tank process menggunakan kontroler Model Predictive Control yang dapat bekerja memprediksi perilaku sistem pada masa depan yang bergantung pada informasi sistem saat ini.

Pada pengujian didapatkan nilai $\mathrm{Np}$ sebesar 10, nilai Nc sebesar 1, dan nilai tuning parameter sebesar 0,2 . Sistem mengalami settling time pada detik ke-39,1002 pada tangki 1 dan detik ke40,1051 pada tangki 2. Sistem mempunyai error steady state sebesar $0,015 \%$ pada tangki 1 dan $0,005 \%$ pada tangki 2 .
\end{abstract}

Kata Kunci - Coupled Tank, Dekopling, Model Predictive Control, Observer

\section{PENDAHULUAN}

Dada industri proses seperti industri petro-chemical, pembuatan kertas, dan industri pengolahan air yang melibatkan cairan, suatu cairan akan dipompa dan dialirkan dari satu tangki ke tangki yang lain untuk diolah. Ada beberapa jenis tangki yang banyak digunakan pada industri proses. Ada jenis tangki yang tidak terhubung dengan tangki yang lain (single tank) dan ada yang tersusun dari beberapa tangki yang saling berhubungan (coupled tanks). [1]

Coupled tanks digolongkan pada plant dengan sistem Multi Input Multi Output (MIMO) atau proses Multivariable. Pengaturan pada plant MIMO lebih sulit dibanding plant dengan sistem Single Input Single Output (SISO). Karena adanya interaksi silang antara variabel masukan dan keluaran, sehingga metode kontrol yang diterapkan pada sistem SISO bisa tidak dapat digunakan secara baik pada sistem MIMO. [2]
Pada pengaturan level air di coupled tanks, level pada tangki kedua akan dipengaruhi oleh aliran cairan dari tangki pertama. Pemindahan cairan dari satu tangki ke tangki yang lain meyebabkan berubahnya level cairan dalam tangki. Dalam pengaturan level, pemindahan cairan biasa disebut sebagai pembebanan pada level. Perubahan beban ini dapat mempengaruhi dari kinerja kontroler.

\section{TINJAUAN PUSTAKA}

A. $\quad$ Coupled Tank [2]

Coupled Tank tersusun dari dua buah tangki yang dihubungkan oleh sebuah pipa atau lubang saluran. Level cairan pada tangki pertama ditunjukkan sebagai $\mathrm{H}_{1}$ dan $\mathrm{H}_{2}$ adalah level tangki kedua. Bila input kontrol adalah flow $\mathrm{Q}_{1}$, maka variabel yang akan dikontrol adalah kedua level $\mathrm{H}_{1}$ dan $\mathrm{H}_{2}$, dengan disturbance yang disebabkan oleh variasi flow pada valve A, valve $\mathrm{B}$. Disini akan timbul suatu sistem dengan dua tangki saling berinteraksi.

Sistem Coupled Tank dapat dikonfigurasi sebagai sestem SISO atau sebagai Sistem MIMO melalui manpulasi input dan sectional daerah valve.

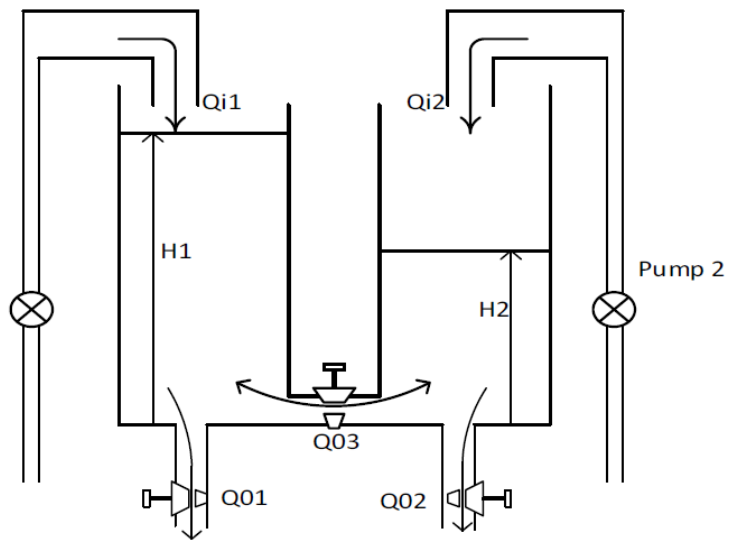

Gambar 1. Bentuk Coupled Tank

Untuk pengaturan level, komponen yang dipakai berupa servo valve, yang mengatur besar kecilnya volume air yang dikeluarkan. Semakin terbuka kondisi dari servo valve maka aliran air yang keluar akan semakin besar, begitu pula sebaliknya. Buka tutupnya pergerakan servo valve diatur oleh sinyal kontrol yang dikirimkan oleh kontroler. 
Indikator merupakan elemen penting pada plant level coupled tank yang berfungsi sebagai evaluasi plant. Indikator ini menunjukkan nilai level dan aliran yang sedang terjadi pada plant level. Nilai ini dijadikan bahan evaluasi oleh kontroler yang selanjutnya digunakan untuk mengatur pergerakan dari servo valve sehingga dapat digunakan utuk mengatur level air.

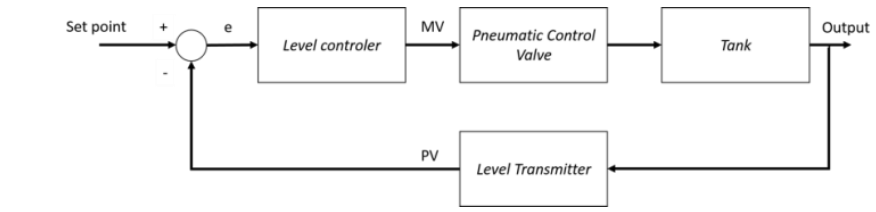

Gambar 2. Diagram Blok Plant

Pengontrolan yang dipakai pada plant ini adalah pengontrolan loop tertutup dengan feedback. Aksi pengontrolan ini keluarannya sangat memengaruhi proses pengontrolan sistem. Keluaran yang dihasilkan sangat tergantung pada keluaran pada aksi pengontrolan sebelumnya. Keluaran yang terjadi selalu diumpan balikkan sebagai pembanding untuk keluaran selanjutnya. Apabila terjadi penyimpangan, maka kontroler akan melakukan penyesuaian sendiri untuk meminimalisir penyimpangan tersebut.

\section{B. $\quad$ Model Predictive Control [3]}

Model Predictive Control (MPC) adalah untuk menghitung trayektori dari sinyal kontrol $u$ (manipulated variable) yang akan datang untuk mengoptimalkan perilaku yang akan datang (future behavior) pada sinyal output y pada sebuah plant berdasarkan pada nilai pengukuran saat ini dan prediksi dari nilai output yang akan datang. Objektif dari kontroler MPC adalah untuk menentukan nilai sinyal kontrol (sequence of control moves) sehingga nilai output yang diprediksi akan mendekati nilai setpoint dengan optimal.

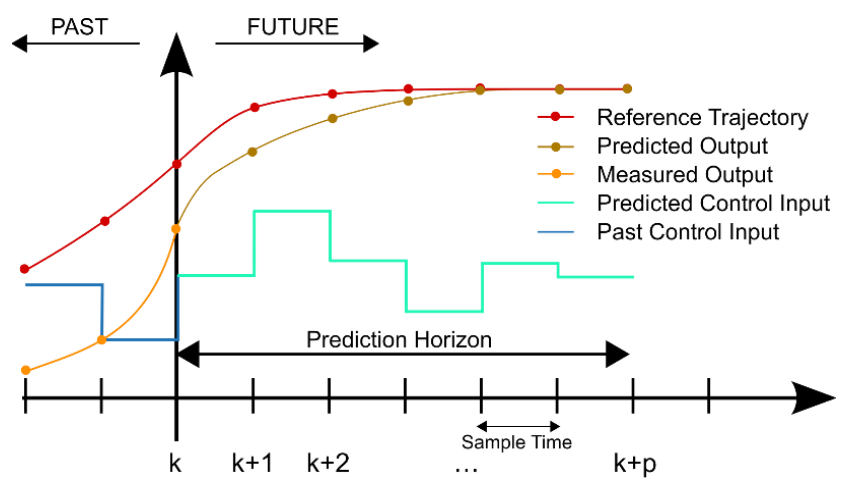

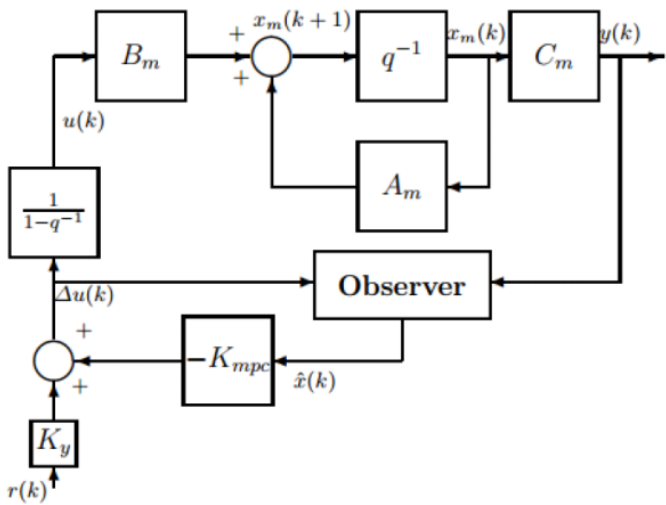

Gambar 3. Struktur Kontroler MPC

Sistem Model Predictive Control didesain berdasarkan oleh model matematika plant. Model plant yang akan digunakan untuk desain system control dirubah menjadi model state space yang diperlukan untuk memprediksi respon kedepan yang diwakilkan oleh variable saat ini. Untuk mempermudah, diasumsikan plant merupakan sistem singleinput dan single output yang dapat dideskripsikan sebagai berikut :

$$
\begin{gathered}
x_{m}(k+1)=A_{m} x_{m}(k)+B_{m} u(k) \\
y(k)=C_{m} x_{m}(k)
\end{gathered}
$$

di mana u adalah variabel manipulasi, y adalah variabel ouput dan xm adalah variabel state. Dikarenakan prinsip dari receding horizon control, dimana state saat ini dibutuhkan untuk menghitung prediksi dan kontrol, maka dapat diasumsikan bahwa input $\mathrm{u}(\mathrm{k})$ tidak dapat mempengaruhi output $\mathrm{y}(\mathrm{k})$ pada waktu yang sama.

Untuk dapat menerapkan kontroler MPC pada suatu plant, maka kita perlu mengubah bentuk state space Persamaan 2 menjadi bentuk augmented model. Adapun bentuk augmented model dapat didefinisikan sebagai Persamaan 3.

$$
\begin{gathered}
\overbrace{\left[\begin{array}{c}
\Delta x_{m}(k+1) \\
y(k+1)
\end{array}\right]}^{x(k+1)}=\overbrace{\left[\begin{array}{cc}
A_{m} & o_{m}^{T} \\
C_{m} A_{m} & 1
\end{array}\right]}^{A}\left[\begin{array}{c}
\Delta x_{m}(k) \\
y(k)
\end{array}\right] \\
+\overbrace{\left[\begin{array}{c}
B_{m} \\
C_{m} B_{m}
\end{array}\right]}^{\Delta u(k)} \\
(k)=\overbrace{\left[\begin{array}{ll}
o_{m} & 1
\end{array}\right]\left[\begin{array}{c}
\Delta x_{m}(k) \\
y(k)
\end{array}\right]}
\end{gathered}
$$

dimana $o_{m}=\overbrace{\left[\begin{array}{lll}0 & 0 & n_{1}\end{array}\right]}^{n_{1}}$, sedangkan matriks A,B, dan C disebut dengan matriks augmented yang akan digunakan untuk desain dari predictive control.

Setelah mendefinsikan augmented model, langkah selanjutnya adalah menentukan matriks predicted output $(F)$ dan matriks future control $(\Phi)$ berdasarkan Persamaan 4.

$$
Y=F x\left(k_{i}\right)+\Phi \Delta U
$$

di mana matriks $\mathrm{F}, \Phi$, dan $\Delta U$ dapat diformulasikan sebagai berikut:

$$
\Delta U=\left[u\left(k_{i}\right) \Delta u\left(k_{i}+1\right) \ldots \Delta u\left(k_{i}+N_{c}-1\right)\right]^{T}
$$




$$
\begin{aligned}
& F=\left[\begin{array}{c}
C A \\
C A^{2} \\
C A^{3} \\
\vdots \\
C A^{N_{p}}
\end{array}\right] \\
& \Phi=\left[\begin{array}{ccccc}
C B & 0 & 0 & \cdots & 0 \\
C A B & C B & 0 & \cdots & 0 \\
C A^{2} B & C A B & C B & \cdots & 0 \\
\vdots & & & & \\
C A^{N_{p-1}} & C A^{N_{p-2}} & C A^{N_{p-3}} & \cdots & C A^{N_{p}-N_{C}}
\end{array}\right]
\end{aligned}
$$

$N_{c}$ merupakan nilai control horizon, yaitu jumlah langkah kontrol berkelanjutan yang diterapkan dan diprediksi oleh kontroler MPC dalam sebuah sampling time. Selain itu, variabel output terprediksi dapat diperkirakan dan diprediksi dalam jumlah sampel $N_{p}$, dimana $N_{p}$ merupakan nilai prediction horizon. Sebagai catatan, nilai $N_{c}$ harus lebih kecil atau sama dengan nilai $N_{p}$.

\section{PERANCANGAN SISTEM}

A. Pemodelan Sistem [4]

Identifikasi Sistem Persamaan plant dapat diperoleh dari persamaan kesetimbangan massa dan hukum Bernoulli. Dinamika plant ini dapat dimodelkan dengan persamaan diferensial sebagai berikut.

$$
\begin{aligned}
& \frac{d H_{1}(t)}{d t}=\frac{\mathrm{k}_{1}}{A} U_{1}(t)-\frac{\beta_{1} a}{A} \sqrt{\frac{g}{2 h_{1}}} H_{1}(t) \\
&+\frac{\beta_{x} a}{A} \sqrt{\frac{g}{2\left|\overline{h_{2}}-\overline{h_{1}}\right|}}\left[H_{2}(t)-H_{1}(t)\right)
\end{aligned}
$$

$$
\begin{aligned}
\frac{d H_{2}(t)}{d t}=\frac{\mathrm{k}_{2}}{A} U_{2}(t) & -\frac{\beta_{2} a}{A} \sqrt{\frac{g}{2 h_{2}}} H_{2}(t) \\
& -\frac{\beta_{x} a}{A} \sqrt{\frac{g}{2\left|\overline{h_{2}}-\overline{h_{1}}\right|}}\left[H_{2}(t)-H_{1}(t)\right)
\end{aligned}
$$

Bentuk transfer function Coupled Tank didapat dari hasil identifikasi sistem sebelumnya, yaitu:

$$
\left[\begin{array}{l}
H_{1}(s) \\
H_{2}(s)
\end{array}\right]=\left[\begin{array}{ll}
G_{11}(s) & G_{12}(s) \\
G_{21}(s) & G_{22}(s)
\end{array}\right]\left[\begin{array}{l}
u_{1}(s) \\
u_{2}(s)
\end{array}\right]
$$

$$
\frac{G_{11}(s)=}{\frac{\frac{k_{1}}{A}\left(s+\frac{T_{\chi}+T_{2}}{T_{2} T_{\chi}}\right)}{s^{2}+\frac{\left(T_{1} T_{\chi}+T_{2} T_{\chi}+2 T_{1} T_{2}\right)}{T_{1} T_{2} T_{x}} s+\left(\frac{1}{T_{1} T_{2}}+\frac{1}{T_{1} T_{x}}+\frac{1}{T_{2} T_{\chi}}\right)}}
$$

$$
\begin{gathered}
G_{12}(s)=\frac{k_{2}}{A}\left(\frac{1}{T_{\chi}}\right) \\
\frac{s^{2}+\frac{\left(T_{1} T_{\chi}+T_{2} T_{\chi}+2 T_{1} T_{2}\right)}{T_{1} T_{2} T_{\chi}} s+\left(\frac{1}{T_{1} T_{2}}+\frac{1}{T_{1} T_{\chi}}+\frac{1}{T_{2} T_{\chi}}\right)}{}
\end{gathered}
$$

$$
\begin{gathered}
G_{21}(s)= \\
\frac{\frac{k_{1}}{A}\left(\frac{1}{T_{\chi}}\right)}{s^{2}+\frac{\left(T_{1} T_{\chi}+T_{2} T_{\chi}+2 T_{1} T_{2}\right)}{T_{1} T_{2} T_{x}} s+\left(\frac{1}{T_{1} T_{2}}+\frac{1}{T_{1} T_{x}}+\frac{1}{T_{2} T_{\chi}}\right)}
\end{gathered}
$$

$$
\begin{aligned}
& G_{22}(s)= \\
& \frac{\frac{k_{2}}{A}\left(s+\frac{T_{\chi}+T_{1}}{T_{1} T_{\chi}}\right)}{s^{2}+\frac{\left(T_{1} T_{\chi}+T_{2} T_{x}+2 T_{1} T_{2}\right)}{T_{1} T_{2} T_{x}} s+\left(\frac{1}{T_{1} T_{2}}+\frac{1}{T_{1} T_{\chi}}+\frac{1}{T_{2} T_{\chi}}\right)}
\end{aligned}
$$

$$
T_{1}=\frac{A}{\beta_{1} a} \sqrt{\frac{2 \overline{h_{1}}}{g}}, \quad T_{2}=\frac{A}{\beta_{2} a} \sqrt{\frac{2 \overline{h_{2}}}{g}}, T_{1}=\frac{A}{\beta_{1} a} \sqrt{\frac{2\left|\overline{h_{1}}-\overline{h_{2}}\right|}{g}}
$$

Lalu ditentukan parameter dan titik kerja untuk plant yang ditunjukkan pada tabel sebagai berikut.

Tabel 3. 1 Parameter Sistem

\begin{tabular}{cc}
\hline$A\left(\mathrm{~cm}^{2}\right)$ & 66,25 \\
$a\left(\mathrm{~cm}^{2}\right)$ & 0,1963 \\
$\beta_{1}$ & 0,35903 \\
$\beta_{2}$ & 0,45848 \\
$\beta_{x}$ & 0,38705 \\
\hline \multicolumn{2}{c}{ Tabel 3. 2 Titik Kerja Plant } \\
\multicolumn{2}{c}{} \\
$u_{1}(V)$ & 2,5 \\
$u_{2}(V)$ & 2 \\
$h_{1}(x 10 \%$ Range $)$ & 2,749 \\
$h_{2}(x 10 \%$ Range $)$ & 3,262 \\
$k_{1}\left(\mathrm{~cm}^{3} /\right.$ V.s $)$ & 2,88 \\
$k_{2}\left(\mathrm{~cm}^{3} /\right.$ V.s $)$ & 2,588 \\
\hline
\end{tabular}

Dengan masukannnya berupa tegangan ke pompa yang ditunjukkan dalam lambang $u_{1}(t), u_{2}(t)$. Keluarannya berupa ketinggian air pada tangki 1 dan 2 yang ditunjukkan dalam $h_{1}(t), h_{2}(t)$.

$$
\begin{aligned}
& G_{11}(s)=\frac{0,22623 s+1,15898 e-3}{s^{2}+0,01755 s+6,3009 e-7} \\
& G_{11}(s)=\frac{-0,00070829}{s^{2}+0,01755 s+6,3009 e-7} \\
& G_{11}(s)=\frac{-0,0017427}{s^{2}+0,01755 s+6,3009 e-7} \\
& G_{11}(s)=\frac{0,442288 s+2,19332 e-3}{s^{2}+0,01755 s+6,3009 e-7}
\end{aligned}
$$

B. Dekopling

Pada sistem Coupled Tank Plant ini, masing-masing input mempengaruhi kedua output. Oleh karena itu, dirancang 
suatu metode dekopling untuk menghilangkan pengaruh interaksi input-output. Dekopling yang akan dirancang ini, dapat meminimalisir gangguan pada plant, ketika salah satu input diberi gangguan sehingga membuat plant menjadi lebih stabil.

Persamaan dekopling didapat dari memasukkan nilai matriks transfer function Coupled Tank Plant yang telah didapatkan dari persamaan (6) sampai (9). Persamaan matriks didapat dari penghitungan sebagai berikut:

$$
D(s)=\left[\begin{array}{cc}
1 & \frac{-G_{12}(s)}{G_{11}} \\
\frac{-G_{21}(s)}{G_{22}(s)} & 1
\end{array}\right]
$$

Transfer function yang didapat adalah sebagai berikut:

$$
\begin{aligned}
& D_{12}(s)=\frac{-0,00070829}{0,22623 s+1,15898 e-3} \\
& D_{21}(s)=\frac{-0,0017427}{0,442288 s+2,19332 e-3}
\end{aligned}
$$

C. Perancangan Kontroler MPC

1) Perencanaan Model State-Space

Fungsi alih tangki 1 adalah sebagai berikut:

$\frac{Y(z)}{U(z)}=\frac{b_{O} z^{2}+b_{1} z+b_{2}}{z^{2}+a_{1} z+a_{2}}=\frac{0,2262 z+0,001159}{z^{2}+0,0175 z+6,301 e-7}$

Fungsi alih tangki 2 adalah sebagai berikut:

$$
\begin{array}{ll}
Y(z) & b_{o} z^{2}+b_{1} z+b_{2} \\
& \text { Gambar 5. Bentuk Dekopling }
\end{array}
$$

$$
\frac{0,4+\angle<00 \angle T<, 170 د \angle t-J}{z^{2}+0,01755 z+6,3009 e-7}
$$

Bentuk state-space yang digunakan pada Tugas Akhir ini adalah bentuk controllable canonical form. Bentuk state-space untuk orde 2 tersebut mempunyai struktur sebagai berikut.

$$
\begin{gathered}
{\left[\begin{array}{l}
x_{1}(k+1) \\
x_{2}(k+1)
\end{array}\right]=\left[\begin{array}{cc}
0 & 1 \\
-a_{2} & -a_{1}
\end{array}\right]\left[\begin{array}{l}
x_{1}(k) \\
x_{2}(k)
\end{array}\right]+\left[\begin{array}{l}
0 \\
1
\end{array}\right] u(k)} \\
y(k)=\left[b_{2}-a_{2} b_{0} \quad b_{1}-a_{1} b_{0}\right]\left[\begin{array}{l}
x_{1}(k) \\
x_{2}(k)
\end{array}\right]
\end{gathered}
$$

Berdasarkan bentuk di atas, maka model statespace dari Persamaan (13) dan (14) dapat disimpulkan sebagai berikut:

Bentuk state-space pada tangki 1:

$$
\begin{aligned}
& {\left[\begin{array}{l}
x_{1}(k+1) \\
x_{2}(k+1)
\end{array}\right]=\left[\begin{array}{cc}
0 & 1 \\
-6,301 e-7 & -0,0175
\end{array}\right]\left[\begin{array}{l}
x_{1}(k) \\
x_{2}(k)
\end{array}\right]} \\
& +\left[\begin{array}{l}
0 \\
1
\end{array}\right] u(k) \\
& y(k)=\left[\begin{array}{ll}
0,001159 & 0,2262
\end{array}\right]\left[\begin{array}{l}
x_{1}(k) \\
x_{2}(k)
\end{array}\right]
\end{aligned}
$$

Bentuk state-space pada tangki 2:

$$
\begin{gathered}
{\left[\begin{array}{l}
x_{1}(k+1) \\
x_{2}(k+1)
\end{array}\right]=} \\
{\left[\begin{array}{cc}
0 & 1 \\
-6,301 e-7 & -0,0175
\end{array}\right]\left[\begin{array}{l}
x_{1}(k) \\
x_{2}(k)
\end{array}\right]+\left[\begin{array}{l}
0 \\
1
\end{array}\right] u(k)}
\end{gathered}
$$

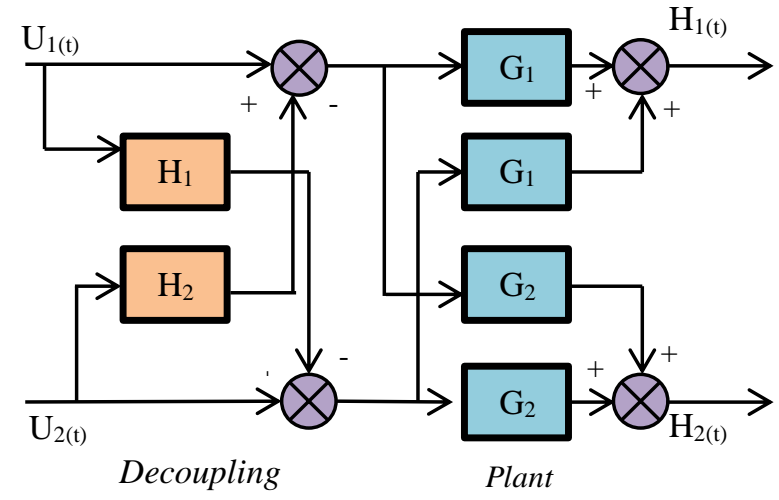

2) Desain Augmented Model

Setelah mendapatkan nilai state-space dari sistem, langkah selanjutnya adalah mengubah statespace tersebut ke dalam bentuk augmented model. Berdasarkan Persamaan (3), dapat disimpulkan bahwa augmented model dari sistem adalah sebagai berikut:

Desain Augmented model untuk Tangki 1:

$\overbrace{\left[\begin{array}{c}\Delta x_{m}(k+1) \\ y(k+1)\end{array}\right]}^{x(k+1)}$
$=\overbrace{\left[\begin{array}{ccc}0 & 1 & 0 \\ -6,301 e-7 & -0,0175 & 0 \\ -0,0000 & -0,0028 & 1\end{array}\right]}^{A} \overbrace{\left[\begin{array}{c}\Delta x_{m}(k) \\ y(k)\end{array}\right]}^{x(k)}$

$+\overbrace{\left[\begin{array}{c}0 \\ 1 \\ 0,2262\end{array}\right]}^{B} \Delta u(k)$

$$
y(k)=\overbrace{\left[\begin{array}{lll}
0 & 0 & 1
\end{array}\right]}^{C}\left[\begin{array}{c}
\Delta x_{m}(k+1) \\
y(k+1)
\end{array}\right]
$$

Desain Augmented model untuk Tangki 2:

$$
\begin{gathered}
\overbrace{\left[\begin{array}{c}
\Delta x_{m}(k+1) \\
y(k+1)
\end{array}\right]}^{x(k+1)}=\overbrace{\left[\begin{array}{ccc}
0 & 1 & 0 \\
-6,301 e-7 & -0,0175 & 0 \\
-0,0000 & -0,0055 & 1
\end{array}\right]}^{B} \\
\overbrace{\left[\begin{array}{c}
\Delta x_{m}(k) \\
y(k)
\end{array}\right]}^{x(k)}+\overbrace{\left[\begin{array}{c}
0 \\
1 \\
0,442288
\end{array}\right]}^{B} \Delta u(k) \\
y(k)=\overbrace{\left[\begin{array}{lll}
0 & 0 & 1
\end{array}\right]\left[\begin{array}{c}
\Delta x_{m}(k+1) \\
y(k+1)
\end{array}\right]}^{C}
\end{gathered}
$$

Matriks A, B, C yang merupakan bentuk augmented model akan digunakan selanjutnya dalam merancang sebuah kontroler MPC.

3) Penentuan Parameter dan Gain Kontroler MPC Pada perancangan kontroler MPC pada tangki 1, akan digunakan parameter prediction horizon sebesar 10 langkah, control horizon senilai 1 langkah, dan tuning parameter indeks perfomansi sebesar 0,2.

Berdasarkan parameter diatas dan Persamaan 4, pada tangki 1 dapat ditentukan matriks $F$ dan $\Phi$ sebagai berikut: 


$$
\begin{gathered}
F=\left[\begin{array}{lll}
-0,0000 & -0,0028 & 1 \\
-0,0000 & -0,0028 & 1 \\
-0,0000 & -0,0028 & 1 \\
-0,0000 & -0,0028 & 1 \\
-0,0000 & -0,0028 & 1 \\
-0,0000 & -0,0028 & 1 \\
-0,0000 & -0,0028 & 1 \\
-0,0000 & -0,0028 & 1 \\
-0,0000 & -0,0028 & 1 \\
-0,0000 & -0,0028 & 1
\end{array}\right] \\
\Phi=\left[\begin{array}{l}
0,2262 \\
0,2234 \\
0,2234 \\
0,2234 \\
0,2234 \\
0,2234 \\
0,2234 \\
0,2234 \\
0,2234 \\
0,2234
\end{array}\right]
\end{gathered}
$$

Setelah mendapatkan matriks $\mathrm{F}$ dan $\Phi$, parameter selanjutnya yang akan dicari adalah gain dari kontroler MPC. Gain tersebut adalah KMPC dan Ky. Untuk mencari nilai KMPC, terlebih dahulu kita harus mencari nilai dari matriks Y sebagai berikut:

$$
Y=\left(\Phi^{T} \Phi+\bar{R}\right)^{-1}\left(\Phi^{T} F\right)
$$

Nilai Gain KMPC merupakan baris pertama dari matriks Y. Nilai Ky merupakan kolom ketiga dari baris pertama matriks $\mathrm{Y}$. Oleh karena itu, nilai gain KMPC dapat kita simpulkan sebagai matriks berikut.

$$
\begin{gathered}
K_{M P C}=\left[\begin{array}{ccc}
-0,0000 & -0,0088 & 3,1937
\end{array}\right] \\
K_{y}=3,1937
\end{gathered}
$$

Pada perancangan kontroler MPC pada tangki 2, akan digunakan parameter prediction horizon sebesar 10 langkah, control horizon senilai 1 langkah, dan tuning parameter indeks perfomansi sebesar 0,2.

Berdasarkan parameter diatas dan Persamaan 4, pada tangki 2 dapat ditentukan matriks $F$ dan $\Phi$ sebagai berikut:

$$
\begin{aligned}
& F=\left[\begin{array}{lll}
-0,0000 & -0,0055 & 1 \\
-0,0000 & -0,0054 & 1 \\
-0,0000 & -0,0055 & 1 \\
-0,0000 & -0,0055 & 1 \\
-0,0000 & -0,0055 & 1 \\
-0,0000 & -0,0055 & 1 \\
-0,0000 & -0,0054 & 1 \\
-0,0000 & -0,0055 & 1 \\
-0,0000 & -0,0055 & 1 \\
-0,0000 & -0,0055 & 1
\end{array}\right] \\
& \Phi=\left[\begin{array}{l}
0,4423 \\
0,4367 \\
0,4368 \\
0,4368 \\
0,4368 \\
0,4368 \\
0,4368 \\
0,4368 \\
0,4368 \\
0,4368
\end{array}\right]
\end{aligned}
$$

Nilai Gain KMPC merupakan baris pertama dari matriks Y. Nilai Ky merupakan kolom ketiga dari baris pertama matriks $\mathrm{Y}$. Oleh karena itu, nilai gain KMPC dapat kita simpulkan sebagai matriks berikut.

$$
\begin{gathered}
K_{M P C}=\left[\begin{array}{lll}
-0,0000 & -0,0113 & 2,0699
\end{array}\right] \\
K_{y}=2,0699
\end{gathered}
$$

\section{HASIL PERCOBAAN DAN ANALISA}

Tahap simulasi digunakan untuk mengetahui performa dari kontroler MPC dalam meminimalkan nilai error antara respon dengan referensi. Tahap simulasi penting dilakukan sebelum tahap implementasi untuk memastikan bahwa perancangan kontroler sudah memenuhi performa yang diharapkan. Blok diagram simulasi ditunjukkan seperti Gambar 6. Secara garis besar, diagram blok simulasi sistem terdiri dari state-space sistem, penguatan atau gain MPC dan subsistem observer. Blok diagram dari simulasi sistem dapat dilihat pada Gambar 6.

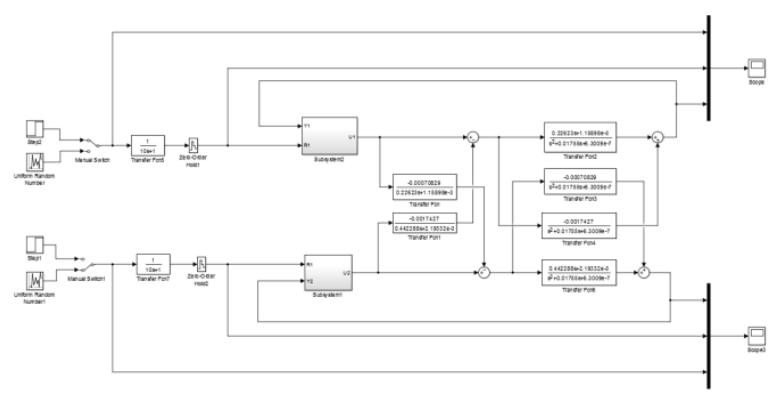

Gambar 6. Simulink Plant

Variabel pertama yang akan diuji pada sistem dan kontroler MPC adalah pengaruh niali prediction horizon atau $N_{p}$. Terlihat dari Gambar 7, bahwa respon yang dihasilkan oleh sistem akan berbeda-beda seiring dengan parameter prediction horizon yang berbeda pula.

Pada nilai $N_{p}=3$, terlihat bahwa respon sudah mengikuti tracking setpoint yang diberikan. Tetapi, seperti terlihat pada Gambar 7, overshoot yang dihasilkan oleh sistem sangat tinggi. Oleh karena itu, perlu di-tuning lagi nilai dari prediction horizon agar respon yang dihasilkan tidak mengalami overshoot.

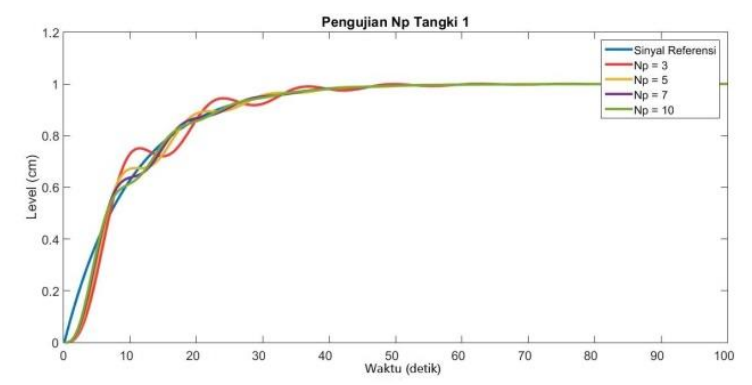

Gambar 7. Respon Tangki 1

Setelah melakukan beberapa kali pengujian, akhirnya ditemukan nilai $N_{p}=10$. Respon yang dihasilkan jauh lebih baik dibandingkan nilai $N_{p}=3$. Respon yang dihasilkan mengalami overshoot paling kecil di antara nilai Np yang lain. Akan tetapi, terlihat bahwa respon yang dihasilkan lebih lambat daripada nilai $N_{p}=3$.

Begitu juga dengan tangki 2 , dipasang nilai $\mathrm{Np}=10$. Respon yang dihasilkan mengalami overshoot paling kecil di 
antara nilai Np yang lain. Akan tetapi, terlihat bahwa respon yang dihasilkan lebih lambat daripada nilai $N_{p}=3$.

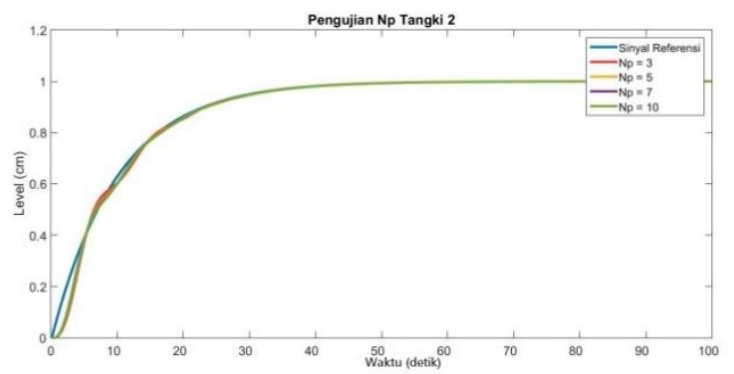

Gambar 8. Respon Tangki 2

Setelah mendapatkan Prediction Horizon dan Control Horizon yang sesuai, Kontroler MPC akan dipasang pada tangki 1 dan tangki 2 untuk melihat apakah sinyal yang dibentuk mengikuti sinyal reference. Gambar 8 menunjukkan respon plant dengan kontroler, terlihat bahwa respon pemodelan tangki 1 dan 2 dengan menggunakan MPC berimpit dengan respon dari model yang diinginkan

Pada Gambar 7 dibawah adalah dimana respon input beban berubah untuk membuktikan bahwa kontroler MPC dapat bertahan pada nilai setpoint ketika diberi disturbance random dengan input yang menunjukan real system bahwa beban tidak dapat terprediksi. Input disturbance random berubah setiap 70 detik, ketika respon kontroler sudah mencapai steady state sesuai pada model yang diinginkan dengan nilai settling sebesar 25,2 detik namun respon asli plant belum mencapai steady state.

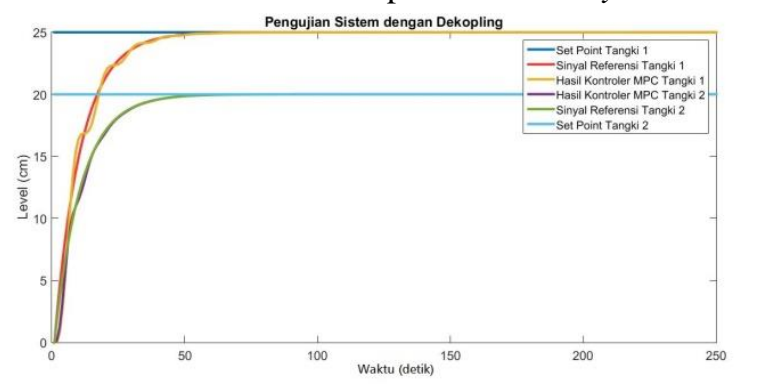

Gambar 9. Respon Plant

Pada pengaturan level pada tangki gangguan beban ini seperti dibukannya valve aliran keluar dari fluida pada saat pengisian fluida ke dalam tangki. Simulasi sistem pengaturan level dengan diberikannya beban ini bertujuan untuk menguji seberapa cepat kontroler mampu mengembalikan respon menuju ke kondisi stabil ketika diberi gangguan. Selain itu juga dilihat seberapa tahan sistem dengan sebuah kontroler dalam menghadapi pembebanan yang ada, dikarenakan juga pembebanan pada sistem dapat mengakibatkan perubahan parameter pada plant.

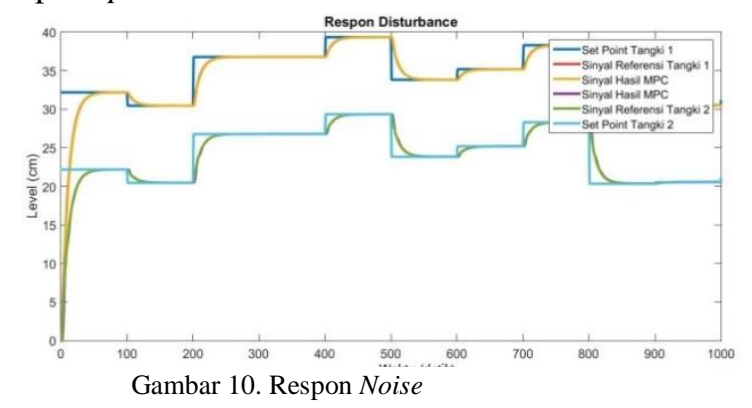

\section{KESIMPULAN}

Dari hasil simulasi, terlihat bahwa respon ketinggian fluida tangki terhadap waktu dapat mengikuti sinyal referensi setelah diberi kontroler MPC. Semakin besar nilai prediction horizon dan tuning parameter, respon yang dihasilkan akan semakin lambat dan halus. Sebaliknya, semakin kecil nilai prediciton horizon dan tuning parameter akan mengakibatkan respon yang semakin cepat walaupun dapat menimbulkan overshoot yang semakin tinggi. Jika nilai control horizon dan tuning parameter semakin besar, maka sistem akan memiliki waktu respon yang lebih cepat dengan kekurangan overshoot yang semakin tinggi. Adapun jika nilai control horizon dan tuning parameter semakin kecil, respon yang dihasilkan sistem akan semakin halus walaupun waktu respon akan semakin lambat.

\section{DAFTAR PUSTAKA}

[1] Muhammad Sadli, "Disain Kontroler PI dengan Decoupling pada Sistem Kendali Level Coupled Tank", Jurnal ECOTIPE, ISSN 2355-5068, Volume 1, No. 2, Oktober 2014.

[2] Arjin Numsomran, "Design of-DOF PI Controller with Decoupling for Coupled-Tank Process," International Conference on Control, Pathumwan Institute of Technology, 2007.

[3] E. F. Camacho, "Model Predictive Control (Advanced Textbooks in Control and Signal Processing)", Spinger, Inggris, 2000.

[4] Chatchaval Pornpatkul, (2009)" Decentralized Fuzzy Logic Controller for TITO Coupled Tanks Process, Procedding IEE, Department of Instrumentation Engineering, Pathumwan Institute of Technology, Bangkok, Thailand, CROSSICE International Joint Conference. 